\author{
Bogusław BEMBENEK ${ }^{1}$ \\ Marzena FRANKOWSKA ${ }^{2}$ \\ Katarina HAVERNIKOVA ${ }^{3}$
}

\title{
CLUSTER POLICY AS A DETERMINING FACTOR FOR DEVELOPMENT OF WORLD CLASS-CLUSTERS
}

\begin{abstract}
The article aims to characterize the significance of cluster policy (cluster-based policy) for the development of world-class clusters. It indicates that the clusters functioning in the European Union (EU) member states are of very diversified nature, which ensues, inter alia, from different conditions (endo - and exogenous) of their development. The evolution of the clustering concept contributed to a greater interest and engagement of governmental organizations of European, national and regional levels in the process of direct and indirect support of cluster development. This kind of support is attributed to cluster policy. This policy, in principle, owing to various actions and instruments undertaken in coordination and stimulating the growth of clusters is supposed to contribute to the maximization of cluster synergy effect, accelerate economic growth, improve the competitiveness of an economy and the development of a knowledge-based economy. A crucial element of this policy is stimulating interactions between business, R\&D sector, business support institutions and local and national government agencies in the development process of entrepreneurial ecosystems. The impact of the cluster policy on the cluster development and formation of world-class clusters is presented at the example of German and French cluster policy which focuses on building the cluster management excellence.

Although they constitute an example of an organization of commercial nature, clusters necessitate active public support. Contemporary cluster policy particularly in EU countries is frequently of horizontal nature. It often consists in offering public support for the development of clusters of the greater competitive potential, which have the real chance of obtaining world-class cluster status. Owing to active R\&D activity and international cooperation with key stakeholders, clusters of this type demonstrate the ability to develop strong cluster value chains. The achievement of the world-class cluster level requires cluster management excellence. Hence, the concepts of world-class clusters and cluster management excellence continuously create new strategic challenges for cluster management.
\end{abstract}

Keywords: cluster, cluster policy, management, development, competitiveness.

\footnotetext{
${ }^{1}$ Bogusław Bembenek, PhD, Faculty of Management, Rzeszow University of Technology, Poland Rzeszow, corresponding author, e-mail: bogdanb@prz.edu.pl

${ }^{2}$ Marzena Frankowska, PhD, Faculty of Management and Economics of Services, University of Szczecin, Poland - Szczecin, e-mail: marzena.frankowska@wzieu.pl

${ }^{3}$ Katarína Havierniková, Ing., PhD, Faculty of Social and Economic Relations, Alexander Dubček University of Trenčín, Slovakia - Trenčín, email: katarina.haviernikova@tnuni.sk
} 


\section{INTRODUCTION}

Due to the increase in the globalization of value chains and dynamic competition within global-level innovation, cluster managers and decision-makers face a strategic challenge of achieving world-class cluster level. It is a highly-complicated undertaking, as it requires high-quality cluster management, great competitiveness of cluster potential, a flexible and internationally developed cluster value chain. Naturally, not every current functioning cluster has a potential of building its strategic competitiveness at world-class cluster level. European clusters, particularly the ones form Central and Eastern Europe, frequently expect measurable public support congruent with their needs, to strengthen their strategic position and approach the world-class cluster level.

European Commission has undertaken numerous actions towards cluster development and the promotion of clustering concept for a dozen years now. Since 2014 in EU policy and financing programs there has been emphasized the value of including clusters into the process of stimulating new lines of business and renewing/modernizing the existing economic sectors. To improve the coordination of cluster policy and other policies between the member states and the national and EU level, and to strengthen the quality of cluster policies there have been established the following institutions: European ClusterPolicy Group, European Cluster Alliance, European Cluster Observatory and European Cluster Collaboration Platform. EU policy gives the member states autonomy as regards the form and the scope of the final cluster support at national and regional levels.

Various models of cluster policies function in EU member states. Despite this, a common problem still encompasses the efficient support for cluster development, diversified in terms of live cycle, industry, geographical scope, critical mass, breadth, depth, the level of activity, growth potential, coordination mechanism, etc. Frequently the governments concentrate on financial support of mainly transnational cluster cooperation, high-tech clusters and strong clusters. However, by this kind of decisions, cluster policymakers create various threats for stable development of the remaining clusters; they can contribute to cluster exclusion. This poses other challenges, particularly for clusters of weaker chances for achieving the world-class cluster status.

The article aims to characterize the significance of cluster policy for the development of world-class clusters. The choice of this research problem ensues from the fact that clusters are still perceived as effective tools of economic and regional development, however more and more frequently the scope and form of support for clusters within cluster policies has been gradually reduced. The following research questions constitute the basis for the presented scientific considerations:

- how cluster policy should be understood?

- how cluster policy can increase the level of cluster development?

- what are the key attributes of world-class clusters?

- what is the prevalence of world-class clusters in the EU?

- how cluster policy affect the formation and development of world-class clusters?

The scientific considerations that are presented in the article are based on selected theoretical research results and desk research. They are conceptual and provide a starting point for further research on the impact of cluster policy on cluster competitiveness perceived from different perspectives: market, sector, cluster management quality and strategic resources (tangible and intangible resources). 


\section{THE STRATEGIC DIMENSION OF CLUSTER POLICY}

Nowadays, there exist numerous definitions of cluster policy. The most common cluster policy definitions are extremely broad in their scope. It causes that the reasons for government intervention within cluster development are very diversified and the scale of this intervention varies. In more general terms, cluster policy can be defined as ${ }^{4}$ :

- specific governmental efforts to support clusters,

- national policy aiming at facilitating the emergence and development of clusters in specific related industries and geographical areas,

- a strategic tool to improve economic competitiveness, innovativeness and the knowledge-based economy through clusters development,

- an instrument to improve national and regional competitiveness,

- a wider set of specific government policy interventions aiming at strengthening existing clusters or facilitating the emergence of new ones,

- all efforts by governments, alone or in a collaborative effort with stakeholders, that are directed at clusters to develop their competitiveness,

- efforts that use clusters and are designed to improve their competitiveness,

- a vital element of building strong innovation systems.

Cluster policy exists in both developed and developing countries and varies depending on clusters needs, structure and types of public support, the characteristics of the location as well as the level and stage of cluster development. It may take different forms and follow different ambitions, ranging from framework policies setting general political objectives to specific cluster programs defining specific measures, allocating funding and organizational responsibilities, and setting specific rules for participation in the program. It needs to be adapted to a particular region and cluster context, since the support for an old automotive cluster is very different than that for a new media cluster, even in the same region ${ }^{5}$.Contemporary clusters can develop not only organically but also because of targeted efforts by policy-makers and practitioners, most notably through cluster projects ${ }^{6}$. If clusters are to be effectively fostered through public policy and private sector initiatives, there is a need for a systematic understanding of the factors that contribute to the creation and development of clusters, and the factors that will influence the success or failure of clusters and cluster policy ${ }^{7}$. Clusters can be characterized by a series of dimensions, including geographic scope, breadth, depth, proximity, and others, such as

\footnotetext{
${ }^{4}$ European Commission, The concept of clusters and cluster policies and their role for competitiveness and innovation: main statistical results and lessons learned, Office for Official Publications of the European Communities, Luxembourg 2008, pp. 31-32; Ch. Ketels, Clusters, cluster policy, and Swedish competitiveness in the Global Economy, The Globalisation Council, Västeras 2009, p. 19; S. Barsoumian, A. Severin, T. van der Spek, Eco-innovation and national cluster policies in Europe. A qualitative review, Greenovate Europe EEIG, Brussels 2011, p. 94.

5 OECD, Cluster policies, www.oecd.org/innovation/policyplatform/48137710.pdf, (access: 1.11.2016).

${ }^{6}$ R. Njøs, S.-E. Jakobsen, Cluster policy and regional development: scale, scope, and renewal, "Regional Studies, Regional Science" 2016, vol. 3, no. 1, p. 146.

${ }^{7}$ D. Arthurs, E. Cassidy, Ch.H. Davis, D. Wolfe, Indicators to support innovation cluster policy, "International Journal of Technology Management" 2009, vol. 46, no. 3, p. 265.
} 
activity base, social capital, critical mass, growth potential, competitive position, and innovative capacity ${ }^{8}$.

Stimulation of cluster development through public intervention congruent with their needs is even more reasonable and purposeful due to their perception as an economic driving force. The rationale for public intervention to foster clusters through various types of support measures such as infrastructure and knowledge-based investments as well as networking activities and training, is an increase in knowledge spill-overs (positive externalities) among key stakeholders within clusters ${ }^{9}$. Cluster policy usually aims at supporting firms' competitive advantage by spurring innovation and productivity through a spatial agglomeration of companies from the same or related industries ${ }^{10}$. Therefore, Ch. Ketelsstressesthatcluster policy ${ }^{11}$ :

- is a field under dynamic development where the clarity of the conceptual discussion has not always kept pace with the efforts of practitioners,

- is motivated by traditional economic arguments on dealing with market failures,

- is focused on the long-term supply-side foundations for economic growth,

- can thus make a contribution to ensuring that the public spending now under way has a positive impact, in the short - as well as in the long-term,

- can provide a superior balance between impact and distortion, but this outcome depends on the specific nature of the instruments used,

- is a mix of activities that support platforms to plan and implement joint action with activities that support such joint actions directly,

- is not about identifying a small number of clusters that will drive economic growth in the future; only the market process can make such a selection. Instead, cluster policy mobilizes competitiveness that upgrades many clusters and enables effective competition between them,

- is a tool that inherently faces the danger of being abused as a shield for distortive industrial policy. To overcome this challenge, it requires strong governance and ultimately strong institutions, including a commitment to competition,

- provides a summary expression for a category of specific policies, just like innovation policy or monetary policy,

- however, offers a superior mix of benefits and costs.

Cluster policy is not a static moment, but rather a complex process formed of different stages. Based on various approaches to cluster policy life cycle (presented in the economic literature) - A. Konstantynova and J. Wilson identified seven cluster policy phases e.g. ${ }^{12}$ :

${ }^{8}$ O. Mauroner, Innovation clusters and public policy - the case of a research-driven cluster in Germany, "American Journal of Industrial and Business Management" 2015, vol. 5, p. 739.

${ }^{9}$ P. Zhelev, Cluster policy and smart specialization - the case of Bulgaria, "Journal of US-China Public Administration" 2014, vol. 11, no. 9, p. 743.

${ }^{10} \mathrm{~T}$. Lehmann, M. Benner, Cluster policy in the light of institutional context - a comparative study of transition countries, "Administrative Sciences" 2015, vol. 5, p. 189.

${ }^{11}$ Ch. Ketels, Clusters, cluster policy, and Swedish competitiveness in the Global Economy, The Globalization Council, Västeras 2009, pp. 21-31, 56-57.

12 A. Konstantynova, J. Wilson, Comparing cluster policies: an analytical framework, Orkestra Working Paper Series in Territorial Competitiveness, Orkestra - Basque Institute of Competitiveness, San Sebastian 2014, pp. 18-21. 
- discussion initiation - established forum or network for communication between all affected stakeholders, awareness of the cluster issue and its potential advantages / disadvantages for the region between main regional stakeholders, trust building,

- economic analysis - organized group for managing economy \& clusters analyzes, in-depth cluster-based analysis for evaluation \& understanding of current situation and perspectives of regional economy, the application of a variety of methods for cluster analysis, clear understanding of main principles and advantages of a clusterbased approach to analysis, choice of clusters is based on unique regional characteristics, sectoral orientation, consensus among the actors of public and private sector, selected clusters fit in with existing policy priorities,

- policy analysis - competence through existing policies, engagement in the review of existing industrial policy, participation of external stakeholders in the policy analyzes \& development, understanding \& defining key reasons/rationales for the choice of using cluster policy, commitment to the clustering by stakeholders,

- policy development - a clearly defined strategy, directed toward more than one cluster, highly considers the peculiarities of clusters, especially with their evolution stage and the region, focus on strengthening national and regional competitiveness, a good mix of other existing policies, which also address clustering \& stimulate the development of business environment in general, engagement in cluster policy appears at different administrative levels, policy makers realize the advantages of the concept and are willing to adopt the change,

- policy implementation - using or combining already developed programs and institutions, understanding the reasoning for cluster policy, different procedural indicators for evaluation of cluster policy, multilevel cooperation, timeframe of the funding is formulated, clusters are primarily supported by public money with constant reduction over time, development of cluster management excellence,

- monitoring and evaluation - integral part of cluster policy, key stakeholders and policy makers have developed a balanced range of methodological approaches to be used for cluster activity analysis, control indicators are formulated, the results increase the awareness of the cluster situation and policy approach,

- policy modification - low efficiency of existing policy, lessons driven from the evaluation are considered and integrated in cluster policy, new assessments are explained and understandable, and correlate with stakeholders needs.

G. Duranton argues that good cluster policy involves solving a very difficult coordination problem and correcting a number of market failures. The cluster policy may have some payoff but its design and implementation is much more complicated than cluster proponents would like us to believe. It need to be designed and implemented in very uncertain environments without being captured by special interests ${ }^{13}$. Only the correct implementation of cluster policy at the regional level will improve the socioeconomic development of the area for several reasons. Firstly, the state, as a result of selforganization is obliged to create conditions for constant self-organization at the territorial level of management. Secondly, by activating the process of globalization, the current cluster-based economic development should be characterized by an increasing

\footnotetext{
${ }^{13}$ G. Duranton, California Dreamin': the feeble case for cluster policies, "Review of Economic Analysis" 2011, vol. 3, pp. 26, 40.
} 
regionalization and glocalization (globalization + localization). Thirdly, in the practice of developed countries the trend of deepening sectoral specialization of the region is becoming increasingly important, resulting in an adequate effort to concentrate certain types of production in regions that have certain advantages. Fourthly, regional governments, using economic and legal instruments may affect cluster development programs, using regional budget funds. Fifthly, also regional government are closer to local business needs and business problems than the national government ${ }^{14}$.

A significant challenge at the stage of cluster policy creation is the provision of conditions favorable for the development of new clusters, e.g., within emerging industries, but also by stimulation of the development of contemporary clusters, to enable them to reach the world-class cluster level in the future. Naturally, the scope and form of support for clusters of low activity and competitiveness still constitute an unsolved problem.

Cluster policy is a key element of competitiveness policies at national and regional levels ${ }^{15}$. It appears not to be a single defined policy but very much a mix of different policies anchored in different government areas and at different policy levels ${ }^{16}$. It is a complex, multi instrument policy, as different interventions may interact, even conflict with each other. The cluster policy intervention is likely to have intended and unintended effects, and may even conflict with other local public policies influencing clusters ${ }^{17}$. Cluster policy is most often integrated or is a part of regional development policy, science and technology policy and/or industrial policy in EU member states. It varies across the member states, which is often caused by a bottom up approach tailored to fit the needs of industries ${ }^{18}$. Cluster-specific policy can be differentiated according to its governance structure and its activity profile. It may cover a broad range of different objectives and activities, for which support is offered ${ }^{19}$. Therefore, cluster policy may be divided into three different categories ${ }^{20}$ :

- facilitating policies directed towards creating a favorable microeconomic business environment for growth and innovation that indirectly also stimulate the emergence and cluster dynamics (most horizontal category),

- traditional framework policies, such as industry and SMEs policies, research and innovation policies, and regional policy that often use the cluster approach to increase the efficiency of a specific instrument,

${ }^{14}$ Y. Polozhentseva, M. Klevtsova, Instruments of development of cluster policy: stages, models, international practice, "Procedia Economics and Finance" 2015, vol. 27, p. 531.

${ }^{15}$ OECD, Competitive regional clusters - national policy approaches, OECD Reviews of Regional innovation, Paris 2007, p. 52.

${ }^{16}$ INNO AG, Clusters and clustering policy: a guide for regional and local policy makers, Committee of Regions, Brussels 2010, p. 76.

${ }^{17}$ E. Uyarra, R. Ramlogan, The effects of cluster policy on innovation, Nesta Working Paper 2012, no. $12 / 05$, p. 17 , https://www.nesta.org.uk/sites/default/files/the_effects_of_cluster_policy_on_ innovation.pdf.

${ }^{18}$ S. Barsoumian, A. Severin, T. van der Spek, Eco-innovation and national cluster policies in Europe. A qualitative review, Greenovate Europe EEIG, Brussels 2011, pp. 15-16,

${ }^{19}$ European Commission, Innovation clusters in Europe: a statistical analysis and overview of current policy support, http://www.central2013.eu/fileadmin/user_upload/Downloads/Tools_ Resources/Cluster.pdfp (access: 12.10.2016).

${ }^{20}$ European Commission, The concept of clusters and cluster policies ..., op. cit., pp. 31-32. 
- development policies aiming at creating, mobilizing or strengthening a particular cluster category resulting in specific sectoral cluster initiatives.

Cluster policy is an important part of EU innovation policy. A significant role of the European Commission in supporting the development of strong clusters in Europe can be categorized as follows ${ }^{21}$ :

- to complement regional and national cluster policies, by further removing barriers to trade, investment and migration within Europe,

- to motivate and strengthen regional and national cluster policies, by developing and promoting a strategic approach to cluster policy in Europe,

- to support the creation of regional and national clusters, by strengthening the knowledge base in Europe and enabling better exploitation of research for innovation, such as through the Framework Program for Research and Development, the new lead market initiative (to help reduce market and technology uncertainty in the process of new product development; which can be seen as an important driver for internationalization of research and development) and Cohesion policy programs,

- to stimulate the development of cross-border clusters and the emergence and reinforcement of strong clusters through trans-European cluster policies.

According to European Commission, modern cluster policies aim to put in place a favorable business ecosystem for innovation and entrepreneurship in which new winners can emerge and thus support the development of new industrial value chains (by building upon the innovation potential of SMEs) and emerging industries (new industrial sectors or existing industrial sectors and value chains that are evolving into new industries). This requires more than merely supporting networking activities and setting up cluster organizations that manage networking and provide support services to SMEs. Thus, modern cluster policies follow a systemic approach that combines different activities, policies, programs and instruments. Presently, good cluster policy requires strategic, consistent and concentrated efforts that are evidence-based and not constrained by vested interests ${ }^{22}$.

\section{TOWARDS WORLD-CLASS CLUSTER: CONTEMPORARY CHALLENGE FOR CLUSTER MANAGEMENT}

Successful clusters have significantly increased their global reach through attracting resources (tangible and intangible), investments, serving global markets, and connecting with other clusters or networks that provide complementary activities in global value chains. Moreover, they integrate all the activities needed to deliver a particular value to

${ }^{21}$ European Commission, Innovation clusters in Europe ..., op. cit.. (access: 12.10.2016).

${ }^{22}$ Smart specialization strategies are key elements of a new, more result-oriented Cohesion Policy focusing on growth through innovation, which is now being implemented. It helps regions at different stages of development to focus on their strengths, to position themselves in global value chains and to team up to build strategic partnerships across Europe with other regions that have complementary strength in similar priority areas. Clusters and cluster policies can facilitate this process and help to maximize the impact of the EUR 121 billion of European Structural and Investment Funds allocated to investment in research and innovation guided by smart specialization strategies. K. Izsak, Ch. Ketels, G. Meier zuKöcker, Th. Lämmer-Gamp, Smart guide to cluster policy, Brussels 2016, pp. 11, 20. 
stakeholders (internal and external). They cross the traditional definitions of industries and of manufacturing versus services ${ }^{23}$. The latest European Cluster Panorama 2016 research shows that 3000 strong clusters across Europe account for more than 54 million jobs and $45 \%$ of all traded industries' wages $(23 \% \text { of the overall economy })^{24}$. Very strong clusters can develop into world-class clusters that constitute innovation and business hubs that are known world-wide ${ }^{25}$.Key attributes of world-class-cluster are as follows ${ }^{26}$ :

- established cluster management organizations are operated by an experienced cluster management team,

- a wide spectrum of cluster management services is offered to cluster participants (cluster coordinator continuously develops new services in collaboration with cluster participants),

- all criteria of cluster management excellence are met,

- a cluster strategy is developed and implemented,

- a significant number of international cooperations or partnerships is established,

- high quality of relevant R\&D and respective infrastructure,

- high potential of the development of new and innovative companies,

- national and international attractiveness of a cluster region,

- critical mass of cluster members including market and technology leaders.

World class-clusters should be open, flexible and attractive to the best talent and expertise available worldwide. For this reason, the efforts at regional, national and EU level should facilitate the establishment of closer and more efficient linkages between strong clusters as well as with leading research institutes within Europe and abroad ${ }^{27}$.

In the view of the European Commission, cluster management should be recognized as a new professional qualification that requires high quality standards and professionalism to efficiently provide the services needed by enterprises and institutions working together in clusters and to fully exploit the benefits ensuing from university-industry-government relations ${ }^{28}$. High quality cluster management is therefore considered essential to promote cluster excellence and is very characteristic of world-class clusters ${ }^{29}$. Both concepts, i.e. cluster management excellence and world-class cluster, should be integrated to measure

${ }^{23}$ European Commission, Innovation clusters in Europe..., op. cit. (access: 12.10.2016).

${ }^{24}$ The wages in strong clusters are close to $3 \%$ higher than in industries not located in such regional hotspots, and the wage gap towards both other traded industries and the overall economy is growing. The strong clusters have shown resilience through the crisis; their share in total traded industry employment and wages has from 2008 to 2014 increased slightly to $45 \%$ (jobs) and $51 \%$ (wages). Ch. Ketels, S. Protsiv, European Cluster Panorama 2016, Center for Strategy and Competitiveness, Stockholm School of Economics, Stockholm 2016, pp. 1, 12-15.

25 Th. Christansen, Th. Lämmer-Gamp, G. Meier zuKöcker, Let's make a perfect cluster policy and cluster programme. Smart recommendations for policy makers, Innovation + Technik GmbH, Berlin, Copenhagen 2012, p. 15.

${ }^{26}$ Th. Christansen, Th. Lämmer-Gamp, G. Meier zuKöcker, Let's make a perfect..., op. cit.,p. 27.

${ }^{27}$ European Commission, Towards world-class clusters in the European Union, Office for Official Publications of the European Communities, Luxembourg 2008, p. 9.

${ }^{28}$ European Commission, Towards world-class clusters in the European Union: implementing the broad-based innovation strategy, http://eur-lex.europa.eu/LexUriServ/LexUriServ.do?uri= COM:2008:0652:REV1:en:PDF (access: 12.10.2016).

${ }^{29}$ Europa InterCluster, White paper: the emerging of European world-class clusters, Europa InterCluster, Brussels 2010, p. 17. 
the success of a cluster (as a whole). However, while the idea of world-class clusters has a comprehensive view on a cluster, the assessment criteria of cluster management excellence focuses only on the cluster management process (Tab. 1).

Table 1. Assessment criteria of cluster development

\begin{tabular}{|c|c|}
\hline $\begin{array}{c}\text { Key criteria } \\
\text { of world-class clusters } \\
\text { (comprehensive perspective on the cluster) }\end{array}$ & $\begin{array}{r}\text { Ke } \\
\text { of cluster maI } \\
(\text { focus on cll }\end{array}$ \\
\hline $\begin{array}{l}\text { Framework conditions: } \\
\text { - quality of cluster sector relevant R\&D } \\
\text { - quality of the education in relevant fields } \\
\text { - dynamic of creating new and innovative companies in } \\
\text { the region } \\
\text { - attractiveness of the region for high potentials and } \\
\text { world-class researchers as well as foreign investments } \\
\text { - existence of innovation stimulating regulation and } \\
\text { public sector demand } \\
\text { Cluster members: } \\
\text { - critical mass of market and technology leaders } \\
\text { developing innovative high tech products and services } \\
\text { - international visibility and reputation of the cluster } \\
\text { and its members and other stakeholders } \\
\text { - commitment and active involvement of key cluster } \\
\text { members in the cluster work } \\
\text { - involvement of competitors } \\
\text { - involvement of cluster members in international co- } \\
\text { operations and linkages to key actors outside the } \\
\text { cluster } \\
\text { Cluster organization (cluster management): } \\
\text { - clusterstrategy and itsimplementation } \\
\text { - professionalization of cluster management within } \\
\text { a range of services to cluster members } \\
\text { - sustainability of financing and appropriate staffing of } \\
\text { the cluster organization } \\
\text { tions and cluster members } \\
\text { companies to thrive, which drive innovation, regional } \\
\text { ditiveness and innovation capability of the cluster } \\
\text { development and competitiveness; the strong link } \\
\text { between clusters on one side and research, develop- } \\
\text { ment and innovation on the other side opens the } \\
\text { opportunity to generate new products, services, } \\
\text { technologies, as well as to explore new scientific } \\
\text { to a sths; the added value of the cluster approach has led } \\
\text { mentong positive impact in terms of compe- }\end{array}$ & 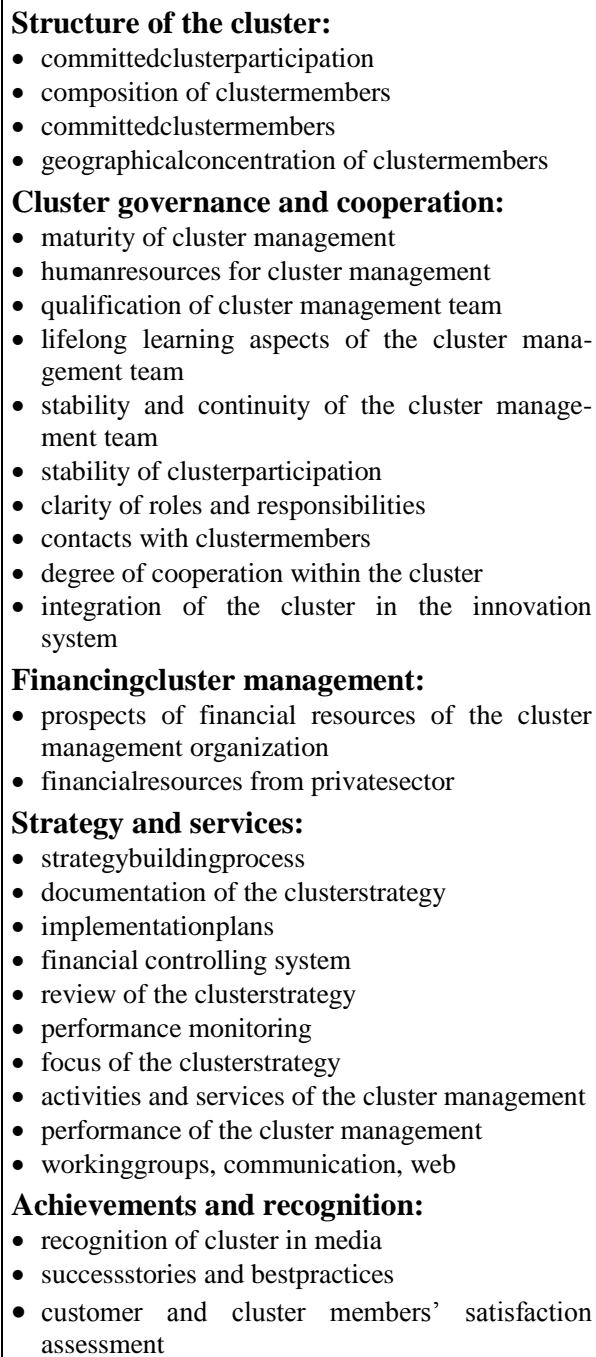 \\
\hline
\end{tabular}

Source: Th. Christansen, Th. Lämmer-Gamp, G. Meier zuKöcker, Let's make a perfect ..., op. cit., p. 17; Europa InterCluster, White paper: the emerging ..., op. cit., p. 23. 
Current research suggests, that the ability of clusters to deliver high quality cluster management and economic performance is often labeled as cluster excellence. The key pillars of excellence in cluster management include a regular review of both cluster objectives and the objectives of the cluster organization, 'trying out' various types of actions and learning from the results of those actions, as well as constant monitoring and regular evaluation, adaptive performance measurement systems and active engagement of cluster stakeholders at all stages of the management ${ }^{30}$. Nowadays, cluster management excellence is considered as a main prerequisite for a cluster organization to achieve the highest impacts within a given technological, industrial, regional, social and legislative framework for the cluster members, the industrial sector and the regional and national economy. Moreover, common standards for excellent cluster management also enable better mutual understanding necessary for transnational cooperation between cluster organizations and hence are important to promote successful cooperation between politics, business and science and international cluster cooperation for the benefit of the participating SMEs ${ }^{31}$.

According to M. Bialic-Davendra clusters are no longer perceived as isolated organizations but as entrepreneurial eco-systems with ambitions to become world-class clusters, internationally visible and with intensive involvement of their stakeholders in international co-operations and linkages across borders. The development of various forms of inter-cluster cooperation such as trans-national, cross-border and/or interregional cooperation among clusters and companies collaborating within their structures has been popularized for example in policy documents in Europe in recent years including Visegrad Group countries (also known as the "Visegrad Four" or simply "V4") $)^{32}$. In turn, Z. Przygodzki argues that V4 countries should clearly: firstly, engage themselves into the construction of a systemic, long-term support for economic networks including clusters; and secondly, shift the support from the current focus on organization and stimulating cooperation to investments in support of innovation and competitiveness of clusters in order to strengthen the potential of innovative businesses ${ }^{33}$.

The success, for example, of the Silicon Valley as a world-class cluster is the bestknown proof that strong clusters are among the most relevant microeconomic factors that influence the levels of prosperity of a region ${ }^{34}$. Silicon Valley has a regional network based industrial system, comprising small firms that collaborate and promote collective learning (organizational learning). Relationship between firms and their customers, suppliers and competitors flourished in regional agglomerations where repeated interaction builds shared identities and mutual trust (high social capital). The firms are

${ }^{30}$ J.H. Schretlen, K. Dervojeda, W. Jansen, B. Schaffmeister, Uncovering excellence in cluster management, PWC, Amsterdam 2011, p. 3.

${ }^{31}$ S. Hantsch, H. Kergel, T. Lämmer-Gamp, G. Meier zuKöcker, M. Nerger, Cluster management excellence in Germany, European Secretariat for Cluster Analysis, Berlin 2013, p. 3.

${ }^{32} \mathrm{M}$. Bialic-Davendra, An investigation of a new concept of world-class clusters in Europe: a case study of the Visegrad Group of countries, "Journal of Competitiveness" 2011, no. 2, pp. 54-55.

${ }^{33}$ Z. Przygodzki, State of play and sectoral differentiation of clusters in Visegrad Group Countries and in Germany in the context of increasing competitiveness, "Comparative Economic Research" 2012, vol. 15, no. 1, p. 78.

${ }^{34} \mathrm{M}$. Trandafir, M. Panaitescu, Clusters and financial resources management in the context of the EU strategy for the Danube region, "Journal of Danubian Studies and Research" 2015, vol. 5, no. 1, p. 81 . 
quick to react to changing business needs yet they are able to tap on mutual resources and successful business ideas. The region's dense social networks and open labor markets encouraged experimentation and entrepreneurship ${ }^{35}$.

The development of Aviation Valley (158 cluster members) is an excellent example of Polish world-class cluster. It is a good case, how cluster critical mass, related industries, location and linkages between business, $\mathrm{R}+\mathrm{D}$ sector, local government have impact on the development of a strong regional economy. Significant funding for the cluster initiative has been provided by Pratt \& Whitney, a world leader in the design, manufacture and service of aircraft engines, space propulsion systems and industrial gas turbines. The reasons for setting up the Aviation Valley were first of all to improve the existing manufacturing base, develop a low-cost supply chain built on the SME base in the region and to create favorable conditions for the aerospace business. The promotion of cooperation, research, technology development and innovation has also been a focus of the cluster, as it regards advanced technologies that allow firms to participate in the biggest international aircraft programs and ensure competitiveness in the long term ${ }^{36}$.The strategic objective of the Aviation Valley is to transform southeastern Poland into one of Europe's leading aerospace regions, which would be able to provide a diverse cross section of products and services for the most demanding clients ${ }^{37}$.

\section{THE IMPACT OF CLUSTER POLICY ON THE EMERGENCE OF WORLD-CLASS CLUSTERS: GERMAN AND FRENCH EXPERIENCES}

The determination of the impact of cluster policy on the formation of world-class clusters requires adoption of certain assumptions, due to the limited scope of this article. Whereas within the cluster policy the identification of the instruments of influence on the formation and development of clusters in a given country is possible, the interpretation of the term "world-class clusters" needs clarification.

According to the earlier position of the EU presented the geographical coverage and the potential of the cluster are not so essential as the high quality of the cluster management for the successful world-class clusters. Therefore, in order to create more world-class clusters across the EU by strengthening cluster excellence, in 2009 the European Commission launched the European Cluster Excellence Initiative (ECEI) ${ }^{38}$.

${ }^{35}$ A.T. Kuah, Cluster theory and practices: advantages for the small business locating in a vibrant cluster, "Journal of Research in Marketing and Entrepreneurship", vol. 4, no. 3, p. 218.

${ }^{36}$ K. Izsak, Ch. Ketels, G. Meier zuKöcker, Th. Lämmer-Gamp, Smart guide ..., op. cit., p. 15.

${ }^{37} \mathrm{http} / / / w w w . d o l i n a l o t n i c z a . p 1 / e n / a b o u t-u s /$ (access: 1.12.2016).

${ }^{38}$ The European Cluster Excellence Initiative, initiated by the European Commission DG Enterprise and Industry, developed methodologies and tools to support cluster organisations to improve their capacities and capabilities in the management of clusters and networks. Being members of the European Cluster Excellence Initiative 13 project partners from nine European countries - all well experienced in the field of cluster management and support - created a uniform set of cluster management quality indicators and developed a quality labeling system for professional cluster management with the aim to get this methodology and proof of quality accepted all over Europe. The European Secretariat for Cluster Analysis (ESCA) offers services in two areas: ESCA promotes cluster management excellence through benchmarking and quality labelling of clusters and cluster management organizations. ESCA has been mandated by the European Cluster Excellence Initiative (ECEI) to organise the assessment process. ESCA supports cluster policy 
Excellent management is considered the main precondition for a cluster organization to attain the highest impact within a given technological, industrial, regional, and legislative framework for the cluster participants, the industrial sector in general, or the development of regions. What is more, common standards for excellent cluster management also enable better mutual understanding which is necessary for transnational cooperation between cluster organizations and, as a result, are important to promote successful international cluster cooperation for the benefit of the participating $\mathrm{SMEs}^{39}$. For this reason, the European Cluster Excellence Initiative developed an assessment scheme for distinguishing cluster organizations which demonstrate highly sophisticated cluster management and are committed to further improve their organizational structures and routines for the benefit of an even higher performance. These clusters organizations receive The "Cluster Management Excellence Label GOLD - Proven for Cluster Excellence" which acknowledges their status as world-class clusters.

Until now, within the European Union as many as 80 cluster organizations from 16 countries have received the Gold Label, as presented in Table 2. It should be noted that accession to the evaluation process is voluntary for each cluster, as well as associated with a significant financial expense. Hence, one should be aware that this number of 80 worldclass clusters does not include some clusters which also meet the criteria, but for various reasons have not applied for the Gold Label. Nevertheless, it can be assumed that the summary presented in Table 2 reflects the impact of cluster policy for the development of clusters in a given country, including at the level of world-class cluster.

Due to the limited scope of this study, there will be analyzed two countries which have the largest number of world-class cluster, ie. France and Germany. In each of these countries 19 clusters have been awarded the Gold Label. Below are characterized the main principles of cluster policy, together with a description of the main support programmes for clusters.

Germany is the main precursor for cluster policy and cluster initiatives in Europe. Cluster policy in Germany started in 1995 by introducing BioRegioWettbewerbprogramme. It was followed with several support programmes both from the national and federal state level ${ }^{40}$. Presently, the Cluster policy at national level is implemented by two main programmes: the Leading-Edge Cluster Competition and "go-cluster: Exzellentvernetzt!"

German cluster policy is closely linked to the High-Tech Strategy which is developed by the German Federal Government. Its main objective is the recognition that the research and innovation are the main tool of worldwide competition, and they are the key to growth and progress. A crucial factor contributing to the success of the High-Tech Strategy is the

makers and programme owners with advice on cluster programme development. ESCA was established by one of the partners, VDI/VDE Innovation + Technik GmbH, to offer practical advice to cluster management organizations. Today, ESCA is a network of cluster experts from more than 30 countries. http://www.cluster-analysis.org/ (access: 1.12.2016).

${ }^{39}$ S. Hantsch, H. Kergel, M. Nerger, T. Lämmer-Gamp, G. Meier zuKöcker, Cluster management excellence in Germany..., op. cit., p. 3.

${ }^{40}$ D. Dohse, Taking regions seriously: recent innovations in German Technology Policy, [in:] Innovation clusters and interregional competition, J. Bröcker, D. Dohse, R. Soltwedel (eds.), Springer, Heidelberg 2003, pp. 372-394. 
Leading-Edge Cluster Competition ${ }^{41}$ run by the Federal Ministry of Education and Research (BMBF) since 2008. In this scope the Federal Ministry of Education and Research plays a major role in implementing the High-Tech Strategy by investing already more than 360 million euros into this competition. The Leading-Edge Cluster Competition is Germany's first nationwide cluster funding programme, open to all technologies and to be made conditional in a long-term strategy. The winners of the "SpitzenclusterWettbewerb - Mehr Innovation. MehrWachstum" (Leading-Edge Clusters Competition More Innovation. More Growth) succeeded in bringing together the most important partners within the innovation and value-added chain in their respective fields of technology and regions. The funding provided support in implementing their cluster and innovation strategy, by helping them to establish themselves in international leading groups in the long term. In a total of three competition rounds $(2008,2009,2011)$, an independent jury selected 15 Leading-Edge Clusters from more than 80 competitors. These clusters receive funding of up to 40 million euros each over a period of five years.

Table 2. Number of "Cluster Management Excellence Label GOLD" by country

\begin{tabular}{|l|c|c|}
\hline Country & Validgoldlabel (December 2016) & Expiredgoldlabel \\
\hline Austria & 6 & - \\
\hline Belgium & 1 & - \\
\hline Czech Republic & 1 & - \\
\hline Denmark & 8 & - \\
\hline France & 15 & 4 \\
\hline Germany & 12 & 7 \\
\hline Greece & 2 & - \\
\hline Hungary & 1 & - \\
\hline Italy & 2 & - \\
\hline Mexico & 1 & - \\
\hline Norway & 5 & - \\
\hline Portugal & 5 & 1 \\
\hline Slovakia & 1 & - \\
\hline Spain & 5 & - \\
\hline Sweden & 1 & - \\
\hline United Kingdom & 1 & $\mathbf{1 3}$ \\
\hline Total & $\mathbf{6 7}$ & 1 \\
\hline
\end{tabular}

Source: Authors' own processing based on:http://www.cluster-analysis.org/gold-label-new (access: 1.12.2016).

One of the clusters that received financial resources and whichmeet the criteria of the world class cluster, is The BioRegionRhein-Neckar Cluster (BioRN) ${ }^{42}$. The clusterspans

${ }^{41}$ Federal Ministry of Education and Research (BMBF), Germany's Leading-Edge Clusters, WE DO communication GmbH GWA, Berlin 2015, p. 6.

${ }^{42} \mathrm{http} / / /$ biorn.org/biorn-cluster/(access: 1.12.2016); H. Okamuro, J. Nishimura, Local management of national cluster policies: comparative case studies of Japanese, German and French biotechnology clusters, "Administrative Sciences" 2015, vol. 5, p. 225. 
the three federal states of Baden-Württemberg, Rheinland-Pfalz, and Hessen. Despitehavingsuch a cross-staterange, the cluster organization define sitself as a biotechnology cluster with specialized companies located within a radius of $30 \mathrm{~km}$. Traditionally, this cluster area was a core for the chemical industry and life science research in Germany, centeredat the University of Heidelberg. Approximately 200 firms (including 77 biotechnology start-ups) and threemultinational pharmaceutical companies (Roche in Mannheim, Merck in Darmstadt, and Abbott in Ludwigshafen) arelocated in the BioRN Cluster. Excellentuniversities and six top-level public research institute sare also located there, including the University of Heidelberg (with the universityhospital), the German Cancer Research Center (DKFZ), the European Molecular Biology Laboratory (EMBL), and the Max-Planck Institute of Medical Research. Several cluster firms are spin-offs from these research institutes, especially the DKFZ.The BioRegionRhein-Neckar Cluster was supported by a BioRegiosubsidy from 1996 to 2000. To execute this project, the BioRegionRhein-Neckar-Dreiecke.V. (BioRNAssociation) was founded in 1996. In 2008, the BioRNAssociation set upBioRN Cluster Management GmbH (BioRN) to prepare to apply for the national Spitzencluster-Wettbewerbin the first round, and, among the five winners of the competition, it was the only biotechnology cluster. In summary, this cluster policy financially supported 36 research consortia with 24 cluster firms. BioRNis a semipublic limited liability company (similar to BioM) supervised by various regional associations (including the BioRNAssociation) with more than 80 members, the Chamber of Industry and Commerce Rhein-Neckar, and Technology Park Heidelberg. More over, the support from national is very important, however the BioRN's activities are funded mainly by the Federal State of Baden-Württemberg. BioRN is a member of the consortium InnoLife, which has won the call for the Knowledge and Innovation Community (KIC) Healthy Living and Active Ageing (EIT Health) of the European Institute for Innovation and Technology (EIT). With a grant volume of up to 700 million euros and a total project volume of more than 2 billion euros, this is one of the largest publicly funded initiatives in the health sector worldwide.

The cluster of molecular biotechnology and biomedicine in Heidelberg is complemented by research in related sectors at other institutions of the region. Fachhochschule Mannheim (Mannheim University of Applied Technology) focuses on cell culture and screening technologies. University of Mannheim is strong in bioinformatics and applied mathematics and as one of Germany's leading universities in business administration it is providing students with entrepreneurial skills. The University of Kaiserslautern is renowned for its microbiology and mycology department. There is also a Centre for Green Gene Technology for transgenic crop plants in Neustadt/Weinstrasse.Most of the biotech start-ups naturally prefer to stay close to the academic centres. Confronted with high rent and living costs in Heidelberg, however, some companies have discovered that short distances and an excellent motorway system allow them to retain their links with research institutes, even when they are located at lower costs elsewhere in the region ${ }^{43}$.

The most recent tool for the German cluster policy is the "go-cluster" programme ${ }^{44}$ which started in 2012. It is the cluster political excellence activity of The Federal Ministry

\footnotetext{
${ }^{43} \mathrm{http} / / / \mathrm{www}$. nature.com/naturejobs/science/articles/10.1038/nj0046(access: 1.12.2016).

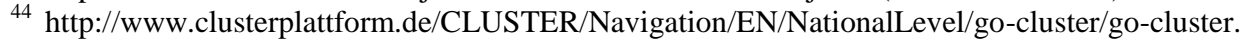
html (access: 1.12.2016).
} 
for Economic Affairs and Energy. The initiative provides support for innovative services and raises the international visibility of innovation clusters. Members of the "go-cluster" programme can obtain funding for novel solutions. Clusters included into the "go-cluster" programme represent innovation of different industries and technological sectors in Germany. Currently around 100 members make use of the various offers of the program. A "go-cluster" membership offers the following multiple advantages to innovation clusters, their actors and cluster-supporting partners:

- a quality and efficiency certificate for cluster management organizations applying uniform assessment criteria that comply with European quality standards,

- assumptions of the costs of the Bronze or Silver Label of the European Cluster Excellence Initiative,

- the right to use the registered word mark/logo "go-cluster: Exzellentvernetzt!" as a quality label,

- participation and higher visibility in government economic initiatives,

- increased national and international visibility to decision-makers representing government, business and administration,

- public presentations of cluster activities and selected success stories on innovation projects (events, newsletters, websites and clusters' success stories "ClusterERFOLGE”),

- networking activities with the most efficient innovation clusters from Germany and Europe,

- participation in seminars on topical matters of clusters and management,

- individual counselling of cluster managements, among others on the issues of strategy development,

- entitlement to apply for funds.

Each German innovation cluster can apply for admission to this programme. The admission requires fulfillment of a set of quality criteria. After a successful application and admission, the participation in the benchmarking processes of the European Cluster Excellence Initiative is mandatory for all members. The cluster management organizations commit themselves to meet the quality criteria of the Silver Label of ECEI within two years in order to record a development and an increase in quality. Within the scope of the "go-cluster" programme The Federal Ministry for Economic Affairs and Energy cover the costs of the benchmarking and certification process and the approval of the Silver Label.Thus, the "go-cluster" programme supports cluster organizations in Germany, with the awareness that the achievement of the status of the world-class Cluster is a long-term process and initially requires excellence at the lower levels (Bronze and Silver Label).

In addition, a support programme already implemented (since 2001) is the "Unternehmen Region - Die BMBF-Innovationsinitiativefür die NeueLänder" (Entrepreneurial Regions - The BMBF Innovation Initiative for the New German Federal States $)^{45}$. It is a measure that focuses on establishing and developing particular technology, science and business skills in former East German regions. The initiative aims to lay the foundations for the development of regional business clusters.

\footnotetext{
${ }^{45}$ Federal Ministry of Education and Research (BMBF), Unternehmen region, Berlin 2015, https://www.bmbf.de/pub/Unternehmen_Region_2_2015.pdf (access: 1.12.2016).
} 
The Local Productive Systems (LPS) in France issued in 1998 is the first national cluster policy ${ }^{46}$. The new industrial policy of France was proclaimed in 2004 in response to the increasing competitiveness on a global scale. One of its main objectives was to support the development of the so-called "pôles de compétitivité" (competitiveness clusters).A "pôle de compétitivité" (PdC) is a partnership, based around a specific theme and a specific region which brings together large and small companies, research bodies and educational entities, all working together in a specific region to develop synergies and cooperative efforts around a shared theme. The important role play also the relations with regional and primarily the national authorities, such as the government. What is more, there are involved various partners in this policy, including the French National Research Agency (AgenceNationale de la Recherche - ANR), Public Investment Bank (Bpifrance), the Environment and Energy Conservation Agency (ADEME), the Deposit and Consignment Fund (Caisse des Dépôts et Consignations - CDC) and Business France.

A competitiveness cluster aims to support innovation. It promotes the development of innovative collaborative research and development (R\&D) projects. It also supports the development and growth of its member companies thanks in particular to the marketing of new products, services or processes resulting from the results of the research projects. The objective is to enable the companies involved to take a leading position in their markets in France and abroad $^{47}$.

The title of the PdC is granted as a result of the evaluation process, and the decision is taken by the interministerial committee CIADT (Comitéinterministérield'aménagement et au développement du territoire), headed by the Prime Minister. The technical back office is assured by DATAR (Délégation à d'aménagement du territoire et l'animationrégionale $)^{48}$. The first PdC's were created in the period September 2004 - July 2005. Currently there are $71 \mathrm{PdC}$ supported. Their functioning is determined by the terms described in the contract which governs the relations between the cluster and the national as well as regional authorities. The main evaluation criteria favour clusters with ${ }^{49}$ :

- a development strategy consistent with the economic development plan of the region where the cluster operates,

- international visibility, both industrially and / or technologically,

- the partnership between actors and a structured and operational mode of governance,

- the ability to create synergies in research and development, thus bringing high added value.

\footnotetext{
${ }^{46} \mathrm{Ph}$. Martin, Th. Mayer, F. Mayneris, Public support to clusters: a firm level study of French "Local Productive Systems", "Regional Science and Urban Economics"2011, vol. 41, no. 2, pp. 108-123.

${ }^{47}$ N. Jacquet, D. Darmon, Les pôles de compétitivité: le modelefrançais, la Documentation Française, Etudes, Paris 2005, p. 27.

${ }^{48}$ P. Dambron, Les clusters en France. Pourquoi les pôles de compétitivité?, L'Harmattan, Paris 2008 , p. 150

${ }^{49}$ Ibidem, p. 124.
} 
There are three stages in the development of cluster policy (la politique des pôles) in France $^{50}$ :

a) stage 1:2005 - 2008. It covers the period of the development of the principles of the functioning of the $\mathrm{PdC}$ and starting them. The assessment of the cluster development for the years 2006-2008 shows that:

- 39 clusters achieved the objectives of the competitiveness poles,

- 19 clusters partially met the objectives of the competitiveness clusters policy and need to work to improve certain dimensions of their action,

- 13 clusters could benefit from a deep reconfiguration,

b) stage 2: 2009-2012, called "Pôle 2.0".With continuation to support R\&D as the basis of the dynamics of the clusters, the second phase comprised the three main areas:

- strengthening the coordination and strategic steering of the clusters, in particular with the implementation of more demanding "performance contracts",

- development of structuring projects, in particular innovation platforms,

- increased support for the development of the innovation's ecosystem and growth of the cluster businesses, in particular through greater use of private funding,

c) stage 3: 2013-2018. The aim is to increase the effectiveness of public action by establishing a closer partnership between national and regional levels. The followingmeasureshavebeenundertaken:

- competitive clusters must become "factories for the future products" that transform the collaborative efforts of R\&D into innovative products, processes and services put on the market,

- future investments will be mobilized to support the industrialization of the cluster projects,

- the offer of collective and individual services proposed by the clusters to their members must be complementary to those implemented by other actors in the region,

- the competitiveness clusters will ensure better involvement of cluster actors,

- the clusters will also contribute to the strengthening of relations between SMEs and major groups, paying particular attention to purchasing,

- for the next 6 years, the objectives of each cluster will be specified in an individualized performance contract. It will detail the technological and innovation challenges and the associated target markets that the cluster wishes to target.

The cluster policy in France is focused on supporting R\&D projects, which is executed:

- through calls for projects launched under the Invest for the Future Programme including the financial assistance for the best nation-wide collaborative publicprivate $R \& D$ projects,

\footnotetext{
${ }^{50}$ French Government, Les Pôles de Compétitivité, http://competitivite.gouv.fr/politique-despoles/la-nouvelle-phase-de-la-politique-des-poles-de-competitivite-949 (access: 1.12.2016).
} 
- by granting loans to member SMEs or ETIs for the industrialization and marketing of the results of a collaborative $R \& D$ project. This loan for the industrialization of cluster projects (PIPC) is financed by the Invest for the Future Programme.

In execution of the "pôles de compétitivité" policy, between 2005 and 2013, more than 1300 collaborative $\mathrm{R} \& \mathrm{D}$ projects received public financing of $€ 2.37$ billion, including more than $€ 1.45$ billion granted by the French State through the dedicated fund (FUI). These projects, amounting to nearly $€ 6$ billion in R\&D expenditure, involved nearly 15000 researchers $^{51}$.

France is a relatively centralized state even though there are 27 regions. The primary way in which regional councils can affect the development of clusters is through expenditure on infrastructure, which includes support to local universities and research institutes.Examples of world class Pôles include Aerospace Valley, which is created in 2005. It is the most significant innovation "pôle de compétitivité" in France in the fields of aeronautics, space and embedded systems, counting with over 840 members from both the industry and the academia. With offices in Toulouse (HQ) and Bordeaux, the innovation cluster covers the two geographically adjacent regions of South-Western France, Occitania and Nouvelle Aquitaine. With 124000 industrial employees, Aerospace Valley represents around $1 / 3$ of the French aerospace workforce. Similarly, 8500 researchers and scientists are active within the Aerospace Valley territory, thus representing $45 \%$ of the French national $R \& D$ potential in the aerospace sector. As of June 2016, Aerospace Valley has obtained funding for 475 R\&D projects representing an accumulated value of 1.2 billion Euro covering most scientific and technical fields related to the various sectors of aerospace. Within the framework of the general French "pôle de compétitivité" program, which aims to stimulate employment by fostering local and regional competencies in technical and economic areas, Aerospace Valley strives to create an ambitious 35-40 000 new jobs by the horizon year $2025^{52}$. Services provided by the cluster include an annual members' event, the possibility to attend strategic business sector seminars, access to sectorial studies, networking and experience exchange and reduced cost access to international trade fairs. Membership also provides opportunities for participating businesses to find partners for innovation projects, obtain financial support from both French government and EU grants and/or venture capital, participate in cooperation with overseas clusters and have access to skills planning forums and access to an internet forum to advertise job positions ${ }^{53}$.

Table 3 summarizes the descriptions of national cluster policies in Germany and France in terms of their main components (institutions, sources, programmes, participating clusters organizations).

\footnotetext{
${ }^{51} \mathrm{http}: / /$ competitivite.gouv.fr/politique-des-poles (access: 1.12.2016).

$52 \mathrm{http}: / /$ www.aerospace-valley.com/en(access: 1.12.2016).

${ }^{53}$ EU best practice in cluster development policy, Maxwell Stamp PLC, Selectio, Zagreb 2012, pp. 27-28, https://poduzetnistvo.gov.hr (access: 1.12.2016).
} 
Table 3. Comparison of National Cluster Policies in Germany and France

\begin{tabular}{|c|c|c|}
\hline Cluster Policy & Germany & France \\
\hline $\begin{array}{l}\text { mainnational } \\
\text { program }\end{array}$ & $\begin{array}{c}\text { Spitzencluster- Wettbewerb } \\
\text { (Leading-Edge Cluster } \\
\text { Competition) }\end{array}$ & $\begin{array}{c}\text { Pôles de Compétitivité } \\
\text { (Competitiveness Clusters) }\end{array}$ \\
\hline period & $\begin{array}{c}2008-2012 \text { (first) } \\
2010-2014 \text { (second) } \\
2012-2016 \text { (third) }\end{array}$ & $\begin{array}{l}2006-2008 \text { (first) } \\
2009-2011 \text { (second) } \\
2013-2018 \text { (third) }\end{array}$ \\
\hline budget & $\begin{array}{l}\text { EUR 600 million } \\
(2008-2016)\end{array}$ & $\begin{array}{c}\text { EUR 2,37 billion } \\
(2005-2013)\end{array}$ \\
\hline $\begin{array}{c}\text { preferredcluster } \\
\text { profile }\end{array}$ & industrial & technological \\
\hline program initiator & $\begin{array}{c}\text { Federal Ministry } \\
\text { of Education and Research } \\
(\mathrm{BMBF})\end{array}$ & $\begin{array}{l}\text { Ministry of Economy, Finance } \\
\text { and Industry }\end{array}$ \\
\hline source of funding & $\mathrm{BMBF}$ & $\begin{array}{l}\text { Inter-ministry Funds (FUI) } \\
\text { and others }\end{array}$ \\
\hline $\begin{array}{l}\text { number of } \\
\text { selected } \\
\text { clusters }\end{array}$ & $\begin{array}{c}15 \\
\text { (sum of } 3 \text { periods) }\end{array}$ & $\begin{array}{c}71 \\
\text { (sum of } 3 \text { periods) }\end{array}$ \\
\hline $\begin{array}{c}\text { number of } \\
\text { submitted } \\
\text { applications }\end{array}$ & $\begin{array}{c}85 \\
\text { (sum of 3periods) }\end{array}$ & $\begin{array}{c}105 \\
\text { (sum of } 3 \text { periods) }\end{array}$ \\
\hline $\begin{array}{c}\text { number of } \\
\text { "Cluster } \\
\text { Management } \\
\text { Excellence Label } \\
\text { GOLD" }\end{array}$ & 19 & 19 \\
\hline
\end{tabular}

Source: Authors' own processing based on: http://competitivite.gouv.fr/politique-des-poles; http://www.clusterplattform.de (access: 1.12.2016); H. Okamuro, J. Nishimura, Local management of national cluster policies: comparative case studies of Japanese, German and French biotechnology clusters, “Administrative Sciences” 2015, vol. 5, pp. 227-228.

The comparative analysis of the German and French cluster policy points to the diverse possibilities of its implementation. Although the goal is similar, both the conditions and the methods adopted by the two states differ from each other. In France, there is a clear correlation between the inception of a national cluster policy and a related cluster funding programme (Les Pôles de Compétitivité) as well as the establishment of cluster organizations, whereas the German cluster policy - even during the early phase was dedicated to further development of the already existing clusters and cluster organizations. Their emergence was supported in several previous activities. That is the reason why the creation of cluster organizations in Germany are spread in time. Moreover, German clusters are predominantly more influenced by the industry. This can be explained by the fact that the French cluster policy (Les Pôles de Compétitivité) more 
significantly aims at and focuses on promoting (labelling) collaborative R\&D projects between research organizations, universities and industry ${ }^{54}$.

In summary, the cluster policy in both countries has a significant impact on the formation of world-class clusters. It focuses on building the cluster management excellence, which is necessary to raise funds for the development and expansion of clusters.The discussion in this paper focuses on national cluster policies. Nevertheless, it is necessary to be also aware of the role of regional cluster policy, which plays an important role especially in Germanyand France ${ }^{55}$.

\section{CONCLUSIONS}

The increase in globalization of the economy increasingly intensifies competition on a global scale. With awareness of these challenges, a number of actions are taken within the European Union which concern, inter alia, the support for innovative clusters in order to build their strong value chains with the potential expansion on a global scale. Thus, cluster policies have attracted increasing attention. Measures are taken on the one hand at the supranational level ie. the European Union, which sees an opportunity to face the global competition as a result of the development of world-class clusters. On the other hand, member states realise their individual cluster policies, which have a significant impact on the level of innovation and internationalization of domestic clusters. The paper has yet some limitation. It is focused on national cluster policy and ignored regional policies by regional government or local authorities which can play an important role. It seems, however, that it is the cluster policy at the national level which has a more significant impact on the development of world-class clusters in a given economy, among other things, thanks to the scope of the financial support offered.

It should be noted that the national cluster policies differ considerably among the European countries. This applies both to the understanding of the role of clusters as well as the ways and the extent of their support. Current research suggests that the ability of clusters to deliver high quality cluster management and economic performance is often labeled as cluster excellence. According to the study in the EU there operate 3000 strong clusters, of which 80 have received the "Cluster Management Excellence Gold Label", which is the top level of cluster excellence and is equivalent to the world-class cluster status. Governments in pursuit of an autonomous cluster policy may use different tools to support the development of clusters. The example of the cluster policy implemented in Germany and France, the two leading EU member states, proves that regardless of the preferences in terms of the profile of clusters (technological or industrial), they are seen as the main tools to compete by means of innovation on the global scale. Policymakers and cluster managers may learn from experience of other countries, specifically how to select and foster competitive clusters.

The scientific considerations presented in this article are based on selected theoretical research results and desk research. The examples of cluster policy implemented in

\footnotetext{
${ }^{54}$ S. Hantsch, H. Kergel, M. Nerger, T. Lämmer-Gamp, G. Meier zuKöcker, Cluster management excellence in Germany..., op. cit., p.8.

${ }^{55} \mathrm{~K}$. Koschatzky, H. Kroll, Which side of the coin? The regional governance of science and innovation, "Regional Studies" 2007, vol. 41, pp. 1115-1127; P. Dambron, Les clusters..., op.cit., p. 135.
} 
Germany and France in comparison with the number of "Cluster Management Excellence Gold Label" functioning there would serve as an illustration of how cluster policy is a determining factor for the development of world-class clusters. The comparative analysis of the German and French cluster policy points to a significant impact of the cluster policy in both countries on the formation of world-class clusters. It focuses on building the cluster management excellence, which is necessary to raise funds for the development and expansion of clusters.

The collected research material provides a starting point for further research on the impact of cluster policy on cluster competitiveness - perceived from different perspectives.

\section{ACKNOWLEDGEMENTS}

This paper is a part of particular goal of the project VEGA 1/0953/16 - The evaluation of clusters' impact measurement on regional development of the Slovak Republic.

\section{REFERENCES}

[1] Arthurs D., Cassidy E., Davis Ch.H., Wolfe D., Indicators to support innovation cluster policy, "International Journal of Technology Management" 2009, vol. 46, no. 3, pp. 263-279.

[2] Barsoumian S., Severin A., van der Spek T., Eco-innovation and national cluster policies in Europe. A qualitative review, Greenovate Europe EEIG, Brussels 2011.

[3] Bialic-Davendra M., An investigation of a new concept of world-class clusters in Europe: a case study of the Visegrad Group of countries, "Journal of Competitiveness" 2011, no. 2, pp. 43-57.

[4] Christansen Th., Lämmer-Gamp Th., Meier zuKöcker G., Let's make a perfect cluster policy and cluster programme. Smart recommendations for policy makers, Innovation + Technik GmbH, Berlin, Copenhagen 2012.

[5] Dambron P., Les clusters en France. Pourquoi les pôles de compétitivité?, L'Harmattan, Paris 2008.

[6] Dohse D., Taking regions seriously: recent innovations in German Technology Policy, [in:] Innovation clusters and interregional competition, J. Bröcker, D. Dohse, R. Soltwedel (eds.), Springer, Heidelberg 2003.

[7] Duranton G., California Dreamin': the feeble case for cluster policies, "Review of Economic Analysis" 2011, vol. 3, pp. 3-45.

[8] EU best practice in cluster development policy, Maxwell Stamp PLC, Selectio, Zagreb 2012, pp. 27-28, https://poduzetnistvo.gov.hr (access: 1.12.2016).

[9] Europa InterCluster, White paper: the emerging of European world-class clusters, Europa InterCluster, Brussels 2010.

[10] European Commission, Innovation clusters in Europe: a statistical analysis and overview of current policy support, http://www.central2013.eu(access: 12.10.2016).

[11] European Commission, The concept of clusters and cluster policies and their role for competitiveness and innovation: main statistical results and lessons learned, Office for Official Publications of the European Communities, Luxembourg 2008. 
[12] European Commission, Towards world-class clusters in the European Union, Office for Official Publications of the European Communities, Luxembourg 2008.

[13] European Commission, Towards world-class clusters in the European Union: implementing the broad-based innovation strategy, http://eur-lex.europa.eu (access: 12.10.2016).

[14] Federal Ministry of Education and Research (BMBF), Unternehmen region, Berlin 2015, https://www.bmbf.de/pub/Unternehmen_Region_2_2015.pdf (access: 1.12.2016).

[15] Hantsch S., Kergel H., Lämmer-Gamp Th., Meier zuKöcker G., Nerger M., Cluster management excellence in Germany, European Secretariat for Cluster Analysis, Berlin 2013.

[16] http://competitivite.gouv.fr/politique-des-poles (access: 1.12.2016).

[17] http://www.aerospace-valley.com/en(access: 1.12.2016).

[18] http://www.dolinalotnicza.pl/en/about-us/ (access: 1.12.2016).

[19] INNO AG, Clusters and clustering policy: a guide for regional and local policy makers, Committee of Regions, Brussels 2010.

[20] Izsak K., Ketels Ch., Meier zuKöcker G., Lämmer-Gamp Th., Smart guide to cluster policy, European Commission, Brussels 2016.

[21] Jacquet N., Darmon D., Les Pôles de compétitivité - le modelefrançais, la Documentation Française, Etudes, Paris 2005.

[22] Ketels Ch., Clusters, cluster policy, and Swedish competitiveness in the Global Economy, The Globalisation Council, Västeras 2009.

[23] Ketels Ch., Protsiv S., European Cluster Panorama 2016, Center for Strategy and Competitiveness, Stockholm School of Economics, Stockholm 2016.

[24] Konstantynova A., Wilson J., Comparing cluster policies: an analytical framework, Orkestra Working Paper Series in Territorial Competitiveness, San Sebastian 2014.

[25] Koschatzky K., Kroll H., Which side of the coin? The regional governance of science and innovation, "Regional Studies" 2007, vol. 41, pp. 1115-1127.

[26] Kuah A.T., Cluster theory and practices: advantages for the small business locating in a vibrant cluster, "Journal of Research in Marketing and Entrepreneurship", vol. 4, no. 3, pp. 206-228.

[27] Lehmann T., Benner M., Cluster policy in the light of institutional context a comparative study of transition countries, "Administrative Sciences" 2015, vol. 5, pp. 188-212.

[28] Mauroner O., Innovation clusters and public policy - the case of a research-driven cluster in Germany, "American Journal of Industrial and Business Management" 2015, vol. 5, pp. 736-747.

[29] Martin Ph., Mayer Th., Mayneris F., Public support to clusters: a firm level study of French "Local Productive Systems", "Regional Science and Urban Economics" 2011, vol. 41, no. 2, pp. 108-123.

[30] Njøs R., Jakobsen S.-E., Cluster policy and regional development: scale, scope, and renewal, "Regional Studies, Regional Science" 2016, vol. 3, no. 1, pp. 146-149.

[31] OECD, Cluster policies, www.oecd.org/innovation/policyplatform/48137710.pdf. 
[32] OECD, Competitive regional clusters - national policy approaches, OECD Reviews of Regional innovation, Paris 2007.

[33] Okamuro H., Nishimura J., Local management of national cluster policies: comparative case studies of Japanese, German and French biotechnology clusters, "Administrative Sciences" 2015, vol. 5, pp. 213-239.

[34] Polozhentseva Y., Klevtsova M., Instruments of development of cluster policy: stages, models, international practice, "Procedia Economics and Finance" 2015, vol. 27, pp. 529-537.

[35] Przygodzki Z., State of play and sectoral differentiation of clusters in Visegrad Group Countries and in Germany in the context of increasing competitiveness, "Comparative Economic Research" 2012, vol. 15, no. 1, pp. 61-81.

[36] Schretlen J.H., Dervojeda K., Jansen W., Schaffmeister B., Uncovering excellence in cluster management, PWC, Amsterdam 2011.

[37] Trandafir M., Panaitescu M., Clusters and financial resources management in the context of the EU strategy for the Danube region, "Journal of Danubian Studies and Research" 2015, vol. 5, no. 1, pp. 79-90.

[38] Uyarra E., Ramlogan R., The effects of cluster policy on innovation, Nesta Working Paper 2012, no. 12/05.

[39] Zhelev P., Cluster policy and smart specialization - the case of Bulgaria, "Journal of US-China Public Administration" 2014, vol. 11, no. 9, pp. 742-749.

\section{POLITYKA KLASTROWA JAKO CZYNNIK DETERMINUJĄCY ROZWÓJ KLASTRÓW ŚWIATOWEJ KLASY}

Celem artykułu była charakterystyka znaczenia polityki klastrowej dla rozwoju klastrów światowej klasy. W artykule wskazano, że funkcjonujące klastry w krajach członkowskich Unii Europejskiej mają bardzo zróżnicowany charakter, co jest efektem m.in. różnych uwarunkowań ich rozwoju (endo- i egzogenicznych). Wraz z rozwojem koncepcji klasteringu zwiększało się zainteresowanie oraz zaangażowanie władz publicznych na poziomie europejskim, narodowym i regionalnym w procesie bezpośredniego i pośredniego wspierania rozwoju klastrów. Tego typu wsparcie było i wciąż jest elementem dotychczasowej polityki klastrowej. Polityka ta z założenia poprzez różne podejmowane działania i instrumenty, w skoordynowany sposób stymulujące rozwój klastrów, przyczynia się do maksymalizowania efektu synergii klastrowej, przyspieszenia wzrostu gospodarczego, poprawy konkurencyjności gospodarki, rozwoju gospodarki opartej na wiedzy. Istotnym elementem tej polityki jest stymulowanie interakcji i powiązań pomiędzy biznesem, sektorem $\mathrm{B}+\mathrm{R}$, instytucjami otoczenia biznesu oraz lokalnymi i krajowymi agencjami rządowymi. Dla zobrazowania wpływu polityki klastrowej na rozwój klasteringu oraz klastrów klasy światowej,dokonano analizy porównawczej polityki klastrowej realizowanej w Niemczech i we Francji.

Klastry pomimo, że stanowią przykład organizacji o charakterze rynkowym, to potrzebują aktywnego wsparcia publicznego. Współczesna polityka klastrowa w poszczególnych krajach UE ma często horyzontalny charakter. W wielu przypadkach koncentruje się na oferowaniu publicznego wsparcia dla rozwoju klastrów o największym potencjale konkurencyjnym, mających realną szansę uzyskania statusu klastra światowej klasy. Klastry tego typu wykazują zdolność rozwoju silnych klastrowych łańcuchów wartości poprzez 
aktywną działalność B+R oraz międzynarodową współpracę z kluczowymi interesariuszami. Osiągnięcie poziomu klastra światowej klasy wymaga doskonałości w zarządzaniu klastrem. Tym samym koncepcje klastra światowej klasy, jak i doskonałości zarządzania klastrem kreują wciąż nowe strategiczne wyzwania dla menedżerów klastrów.

Słowa kluczowe: klaster, polityka klastrowa, zarządzanie, rozwój, konkurencyjność.

DOI:10.7862/rz.2016.hss.59

Przestano do redakcji: wrzesień $2016 r$.

Przyjęto do druku: grudzień 2016 r. 